\title{
The Influence of Organizational Culture and Work Motivation Toward Employee Performance (Case Study On Employees of PT Inoac Polytechno Indonesia)
}

\author{
Nuryasman $\mathrm{MN}^{1)}$ \& Eka Andana Suryaman ${ }^{2)}$ \\ 1). Faculty of Economics, Universitas Tarumanagara, nuryasman@fe.untar.ac.id\& ${ }^{2}$. STIE Lepisi,
} Tangerang

\begin{abstract}
The purpose of this research is to know how big influence of organizational culture variable and work motivation to employee performance, PT. InoacPolytechno Indonesia, PasarKemis, Tangerang. The method used is quantitative method and analyze the relationship between independent variables with dependent variable, measurement method used is using Likert scale by taking 30 respondents from existing population as research sample. For regression test the researcher uses statistical analysis with smartPLS program3.2.6. From the result of research known equation $\mathrm{KK}=0.547(\mathrm{BO})+0.292$ (MK). Organizational culture has a positive and significant impact on employee performance, which has the ability of p-values $0.000<0,05$. While work motivation has positive and insignificant effect on employee's performance, that is having ability of $\mathrm{p}$ values value $0,092>0,05$.
\end{abstract}

Keywords: organizational culture, work motivation and employee performance.

\section{INTRODUCTION}

The enactment of free trade called AEC (ASEAN Economic Community) is directed to provide opportunities for ASEAN member countries to expand the scope of economies, increase prosperity, increase attractiveness as a destination for investors and tourists, reduce trade transaction costs and improve trade facilities and business.In addition, business competition will also be higher.Some general requirements must be owned by a country so that goods and services can compete among ASEAN countries by preparing skilled, intelligent, and competitive human resources.In maintaining and managing the company to continue to grow and develop, the role of human resources has an important position in making changes and determine the success of the company.

According to Putri, (2015) the success of an organization is determined by whether or not an employee's performance. Sutrisno, Fathoni, \& Minarsih, (2016) argue that the contribution of employees in performance is influenced by several variables, namely motivation and work discipline.Meanwhile, according to Fahrurazi, Ghalib, \& Arifin, (2014) the amount of employees' contribution to performance is influenced by communication and organizational culture variables.

Organizational culture at PT. Inoac Polytechno Indonesia is reflected in the values applied by the company. The values applied by the company and listed in the profile of PT. Inoac Polytechno Indonesia is, (1). Honesty, (2) Transparency, (3) Quick Response, (4) Respect Each Other, (4) Learn and Grow Together, (5) Continual Improvement. (Source: PT Inoac Polytechno Indonesia).

Research on the influence of organizational culture and work motivation on employee performance has been done a lot before. But in the study there are many 
differences in results found. In the research that has been done by (Afnita, Muis, \& Umar, 2014; Rimpulaeng \& Sepang, 2014; Sulistyaningsih, Dewi, \& Wijayanti, 2012; Wahyuni, 2015) stated that organizational culture has a significant effect on employee performance. While research conducted by (Lina, 2014, Maabuat, 2016, Masambe, Soegoto, \& Sumarauw, 2015; Satyawati \& Suartana, 2014) shows that organizational culture has no significant effect on employee performance.

Selection of work motivation as an independent variable affecting employee performance has also been done. The research conducted by (Dhermawan, Sudibya, \& Utama, 2012, Fydayeen, Masjaya, \& Prakoso, 2016; Maramis, 2013; Murti, 2013; Suwati, 2013) shows that work motivation has no significant effect on employee performance. In contrast to research conducted by (Aggriawan, Hamid, \& Mukzam, 2015; Bachtiar, 2012, Hendriani \& Hariyandi, 2014; Sari, Muis, \& Hamid, 2012; Tampi, 2014) who stated that work motivation has a significant effect on performance employees.

Based on the background of the above problems, the authors are interested to conduct research on PT. Inoac Polytechno Indonesia by proposing a hypothesis:

$\mathrm{H}_{1}$ : Suspected there is a positive influence between organizational culture and employee performance.

$\mathrm{H}_{2}$ : Suspected there is a positive influence between work motivation and employee performance.

\section{LITERATURE REVIEW}

Performance is the work achieved by the employee in completing the tasks and responsibilities given in a certain period (Fydayeen et al., 2016; Cashmere, 2016). As for measuring employee performance can be used several indicators (Cashmere, 2016) namely, (1). Quality, which is a certain process whereby the process or outcome of the completion of an activity approaches the point of perfection, (2). Quantity, is the amount of production produced can be shown in the form of currency units, number of units or number of cycles completed activities, (3). Timeliness is where the activity or a production result can be completed with the deadline set by the company, (4). Emphasis Costs, costs already budgeted by the company serve as a reference to not exceed the budgeted, (5). Supervision, with supervision, employees will feel more responsible for their work and in case of deviation, supervision will make it easier to make corrections and corrections as soon as possible, and (6). Relationship between employees, an employee is able to develop mutual respect and cooperation among employees to generate better job activity.

Organizational culture is one asset or organizational resource that contains assumptions, values, norms, commitments and beliefs, useful for encouraging and improving the efficiency and effectiveness of public or private organizations (Trang, 2013; Umam, 2015). Robbins quoted in Darmawan, (2013) describes the characteristics of organizational culture as follows, (1). Innovation and courage to take risks, namely the extent to which organizations encourage employees to be innovative and courageous in taking risks, (2). The attention to detail is the extent to which the organization expects employees to show carefulness, analysis, and attention to details, (3). Results-oriented is the extent to which management focuses actions on outcomes rather than attention to the techniques and processes used to achieve those results, (4). Human-oriented is the extent to which management decisions take into account the effect of outcomes on people in the 
organization, (5). Team-oriented is the extent to which work activities are organized around teams, not only in individuals to support cooperation, (6). Aggressiveness is the extent to which the perpetrator of the organization is aggressive and competitive to run the organizational culture as best as possible, and (7). Stability is the extent to which organizational activities emphasize the status quo as a contrast to growth.

Motivation is a set of attitudes and values that affect the individual to achieve the specific in accordance with the individual's goals. Those attitudes and values are the invisible ones that give the power to encourage a person to behave in accomplishing the goal (Rimpulaeng \& Sepang, 2014; Zainal, Ramly, Mutis, \& Arafah, 2014). Maslow's opinion on motivation is based on the level of need (Zainal et al., 2014) comprising, (1). Physiological, among others, the need for clothing, food, boards and other physical needs, (2). Safety, including the need for safety and protection against physical and emotional harm, (3). Social ownership, among others affection, belonging, friendship and acceptable, (4). Self-Appreciation, among others, obtains a higher promotion, is honored for achievement, status, recognition and attention, and (5). Self-actualization, is an incentive to be someone according to his ambition that includes growth, achievement of potential, and self-fulfillment.

Company is an organization founded by a person or group of people in which there are activities of production and distribution of a product to meet the needs of consumers. Every company has an organizational culture that contains the values applied by the company. Organizational culture and employees have an equally important attachment to the company. Employees act as a driver for all activities within the company, and the existence of organizational culture acts as the norms, guidelines and rules that bind employees, so that employees can have good performance, run the company's mission to achieve the goals or vision of the company.

In addition to organizational culture that can affect employee performance, discipline, communication and work motivation also affect the employee's performance. Work motivation is an encouragement given to employees in order to work better. The performance of employees in a company will affect the productivity, effectiveness of the system has been made, cost efficiency incurred, and profits to be obtained by the company.

\section{METHOD}

This research was conducted at PT. Inoac Polytechno Indonesia, having its address at Jalan Agarindo KM. 6, Desa Sukamantri, Pasarkemis, Tangerang, 15560, BantenIndonesia. Population and sample in this research is all leadership or head of section at PT. Inoac Polytechno Indonesia as many as 30 respondents.

The sampling technique used is a saturated sampling technique that is sampling where all members of the population are sampled because the population is relatively small (Sugiyono, 2016). All members of the population of 30 respondents, used as research samples. Data collection techniques in this study using a questionnaire addressed to all leaders or head of department at PT. Inoac Polytechno Indonesia. The questionnaire is filled in accordance with the item of question or statement to obtain the required data using Likert scale with five alternative answers.

The model used in this study uses Structural Equation Modeling (SEM) which is estimated using SmartPLS (Smart Partial Least Square) software assistance. Data analysis 
and structural equation modeling using SmartPLS software has several steps as follows (Garson, 2016, Noor, 2014), (1). Test the validity of the indicator, (2). Convert the path diagram into the equation system, (3). The construct reliability test, (4). Hypothesis Testing, (5). Equations of Inner Model and. (6). Evaluation of Structural Model.

To obtain data and information from respondents related to organizational culture research variable $(\mathrm{BO})$, work motivation $(\mathrm{MK})$ and employee performance $(\mathrm{KK})$ required indicators for each variable with measurement scale for each variable such as Strongly Disagree (STS $=1)$, Disagree $(\mathrm{TS}=2)$, Less Agree $(\mathrm{KS}=3)$, Agree $(\mathrm{S}=4)$ and Strongly Agree (SS = 5).

Indicators for organizational culture (BO) consist of (a). Innovation and courage take risks, (b). Attention to detail, (c). Orientation of results, (d). Orientation to human resources, (e). Orientation to teamwork, (f). Aggressiveness, (g). Stability, (h). Honesty, (i). Transparent, (j). Response, (k). Mutual respect, ((l) Learn and grow together, and (m) Continual improvement (Darmawan, 2013).

Job motivation variable (MK) has indicator (Zainal et al., 2014) as follows, (a). Physiological, (b). Safety, (c). Social ownership, (d). Self-actualization, and (e). Appreciation. For employee performance variables (KK) the indicator used is quoted from (Kasmir, 2016) consisting of, (a). Quality, (b). Quantity, (c). Time, (d). Cost, (e). Supervision, and (f). Relationship between employees.

\section{ANALYSIS AND DISCUSSION}

Descriptive Analysis of Respondents. The number of respondents from this study as many as 30 people with characteristics as shown in the following table:

Table 1.Characteristics of Respondents

\begin{tabular}{cccc}
\hline \multicolumn{2}{c}{ Respondent's data } & Amount & $\%$ \\
\hline \multirow{2}{*}{ Gender } & Male & 22 & 73.33 \\
& Female & 8 & 26.67 \\
& $<18$ year's old & 0 & 0.00 \\
Age & $18-25$ year's old & 0 & 0.00 \\
& $25-35$ year's old & 5 & 16.67 \\
& $>35$ year's old & 25 & 83.33 \\
& Senior High School & 14 & 46.67 \\
Educational & Diploma & 8 & 26.67 \\
& Undergraduate & 6 & 20.00 \\
& Postgraduate & 2 & 6.67 \\
\hline
\end{tabular}

Source: Author

Based on the above table it can be seen that the majority of respondents as much as 73 percent male sex with the number of 22 people, while the rest are female respondents amounted to 8 people or by 27 percent. This indicates that employees owned by the company are relatively more flexible and have high strength, because in general men, have more power than women and relatively have no obstacles in doing the job.

Characteristics of respondents by age range can be known, the majority of respondents as much as 83 percent or 25 people have an age range over 35 years, while the 
remaining 17 percent or as many as 5 people have an age range of about 25 to 35 years. Based on this it can be said that employees are at the age of productive and generally have a work ethic and high morale.

Based on educational background can be explained, there are 14 people or 47 percent of respondents have educational background of Senior High School, 8 people or 27 percent of respondents have diploma education, 6 people or 20 percent of respondents have undergraduate education. And the rest, as many as 2 people or 7 percent of respondents have postgraduate education. Viewed from this information, it can be concluded in general employees owned by the company are at relatively low levels of education, so this is a barrier and challenge for companies in improving employee performance from the aspect of education.

\section{DESCRIPTION OF RESEARCH VARIABLES}

Descriptive Analysis of Organizational Culture Variable. The result of tabulation on organizational culture variable (BO) with 13 indicators can be seen in table 2 below:

Table 2. Tabulation of Organizational Culture Data (BO)

\begin{tabular}{|c|c|c|c|c|c|c|c|c|c|c|}
\hline \multirow{2}{*}{ Indicators } & \multicolumn{2}{|l|}{1} & \multicolumn{2}{|l|}{2} & \multicolumn{2}{|l|}{3} & \multicolumn{2}{|l|}{4} & \multicolumn{2}{|l|}{5} \\
\hline & Frequency & $\%$ & Frequency & $\%$ & Frequency & $\%$ & Frequency & $\%$ & Frequency & $\%$ \\
\hline BO1 & 0 & 0 & 0 & 0 & 2 & 7 & 21 & 70 & 7 & 23 \\
\hline $\mathrm{BO} 2$ & 0 & 0 & 0 & 0 & 0 & 0 & 18 & 60 & 12 & 40 \\
\hline $\mathrm{BO} 3$ & 0 & 0 & 0 & 0 & 0 & 0 & 20 & 67 & 10 & 33 \\
\hline BO4 & 0 & 0 & 0 & 0 & 0 & 0 & 20 & 67 & 10 & 33 \\
\hline $\mathrm{BO} 5$ & 0 & 0 & 0 & 0 & 0 & 0 & 20 & 67 & 10 & 33 \\
\hline BO6 & 0 & 0 & 0 & 0 & 0 & 0 & 15 & 50 & 15 & 50 \\
\hline $\mathrm{BO} 7$ & 0 & 0 & 0 & 0 & 0 & 0 & 16 & 53 & 14 & 45 \\
\hline BO8 & 0 & 0 & 0 & 0 & 0 & 0 & 18 & 60 & 12 & 40 \\
\hline BO9 & 0 & 0 & 0 & 0 & 0 & 0 & 15 & 50 & 15 & 50 \\
\hline BO10 & 0 & 0 & 0 & 0 & 0 & 0 & 19 & 63 & 11 & 37 \\
\hline BO11 & 0 & 0 & 0 & 0 & 0 & 0 & 16 & 53 & 14 & 45 \\
\hline BO12 & 0 & 0 & 0 & 0 & 0 & 0 & 16 & 53 & 14 & 45 \\
\hline BO13 & 0 & 0 & 0 & 0 & 0 & 0 & 20 & 67 & 10 & 33 \\
\hline
\end{tabular}

Source: Author

Based on the table of the frequency of respondents' answers, it can be seen that the respondents no one chose the answer strongly disagree and disagree. When viewed from the mode values, the most answer options on the indicators $\mathrm{BO} 1, \mathrm{BO} 2 \mathrm{BO} 3, \mathrm{BO} 4$ and $\mathrm{BO} 5$ to $\mathrm{BO} 13$ are agreed. This shows that respondents feel that the implementation of organizational culture in the form of accuracy and accuracy in completing the work in accordance with company requirements, orientation to the high work, good cooperation among colleagues, come and go on time, and be open and responsive to problems can making employees work better. 
Descriptive Analysis of Work Motivation Variable. Tabulation of information provided by the respondents to work motivation consisting of 5 indicators presented in table 3 below:

Table 3. Tabulation of Work Motivation Data (MK)

\begin{tabular}{cccccccccccc}
\hline \multirow{2}{*}{ Indicators } & $\mathbf{1}$ & \multicolumn{1}{c}{$\mathbf{2}$} & \multicolumn{2}{c}{$\mathbf{3}$} & \multicolumn{2}{c}{$\mathbf{4}$} & \multicolumn{2}{c}{$\mathbf{5}$} \\
\cline { 2 - 11 } & Frequency & $\mathbf{\%}$ & Frequency & $\mathbf{\%}$ & Frequency & $\mathbf{\%}$ & Frequency & $\mathbf{\%}$ & Frequency & $\mathbf{\%}$ \\
\hline MK1 & 0 & 0 & 0 & 0 & 0 & 0 & 14 & 47 & 16 & 53 \\
MK2 & 0 & 0 & 0 & 0 & 0 & 0 & 18 & 60 & 12 & 40 \\
MK3 & 0 & 0 & 0 & 0 & 0 & 0 & 12 & 40 & 18 & 60 \\
MK4 & 0 & 0 & 0 & 0 & 0 & 0 & 13 & 43 & 17 & 57 \\
MK5 & 0 & 0 & 0 & 0 & 0 & 0 & 13 & 43 & 17 & 57 \\
\hline Source:
\end{tabular}

Table 3 reflects the frequency of respondents' answers, in which the respondents no one chose the answer strongly disagree, disagree and disagree. When viewed from the mode values, the most answer options on the MK1, MK2, MK3, MK4 and MK5 indicators are strongly agreed. This indicates that respondents feel that the provision of work motivation in the form of provision of facilities to help complete the work effectively and efficiently, promotion and career development for employees who excel can make employees work better. In addition, respondents also feel that the provision of work motivation in the form of recognition from the company can make employees work harder.

Descriptive Analysis of Employee Performance Variable. The information given by the respondents to the employee performance variables are presented in table 4 below:

Table 4. Tabulation of Employee Performance Data (KK)

\begin{tabular}{cccccccccccc}
\hline \multirow{2}{*}{ Indicators } & 1 & \multicolumn{2}{c}{2} & \multicolumn{2}{c}{3} & & 4 & \multicolumn{2}{c}{5} \\
\cline { 2 - 10 } & Frequency & $\%$ & Frequency & $\%$ & Frequency & $\%$ & Frequency & $\%$ & Frequency & $\%$ \\
\hline KK1 & 0 & 0 & 0 & 0 & 0 & 0 & 16 & 53 & 14 & 47 \\
KK2 & 0 & 0 & 0 & 0 & 0 & 0 & 15 & 50 & 15 & 50 \\
KK3 & 0 & 0 & 0 & 0 & 0 & 0 & 17 & 57 & 13 & 43 \\
KK4 & 0 & 0 & 0 & 0 & 0 & 0 & 17 & 57 & 13 & 43 \\
KK5 & 0 & 0 & 0 & 0 & 0 & 0 & 17 & 57 & 13 & 43 \\
KK6 & 0 & 0 & 0 & 0 & 0 & 0 & 17 & 57 & 13 & 43 \\
\hline
\end{tabular}

Source: Authors

Based on the frequency table of respondents above, it can be seen that the respondent no one chose the answer strongly disagree, disagree and disagree. When viewed from the mode values, the most answer choice on KK1, KK2, KK3, KK4, KK5 and KK6 indicator are agree. This shows that the respondents feel that the employee performance improvement is evidenced by the employees can work well without reducing the quality of the product in accordance with the standardization of the company and employees who can complete the work according to the target to be achieved by the company. 
Testing Validity Indicators. According to (Garson, 2016; Yamin \& Kurniawan, 2011), validity testing can be performed using convergent validity and discriminant validity.

Test convergent validity is an evaluation performed on each indicator of the construct. Evaluation of convergent validity is done by looking at value of loading factor of each indicator to construct. It is expected that the value of the loading factor to the construct is greater than 0.50 . If the value of the loading factor indicator to the construct is below 0.50 then the indicator must be removed from the model (Garson, 2016; Yamin \& Kurniawan, 2011). Loading factor is the correlation between the indicator and the construct. The higher the correlation, the higher the validity level.

While discriminant validity is a test done by looking at the value of cross loading results. This is done to determine whether each indicator that measures its construct is highly correlated with its own construct compared to other constructs (Garson, 2016; Yamin \& Kurniawan, 2011).

Based on the result of convergent validity testing, loading factor for indicators $\mathrm{BO} 1$, $\mathrm{BO} 4, \mathrm{BO} 7, \mathrm{BO} 8, \mathrm{BO} 11, \mathrm{BO} 12, \mathrm{BO} 13$ as indicators are expected to represent latent variable Organizational Culture (BO), KK3, KK4, KK5 indicators as representation of latent variable Employee Performance (KK) and MK1 and MK2 indicators representing latent variable Work Motivation (MK) has a loading factor below 0.50, which means that the indicatorsare not valid to represent its latent variables, as shown in Figure 1 below.

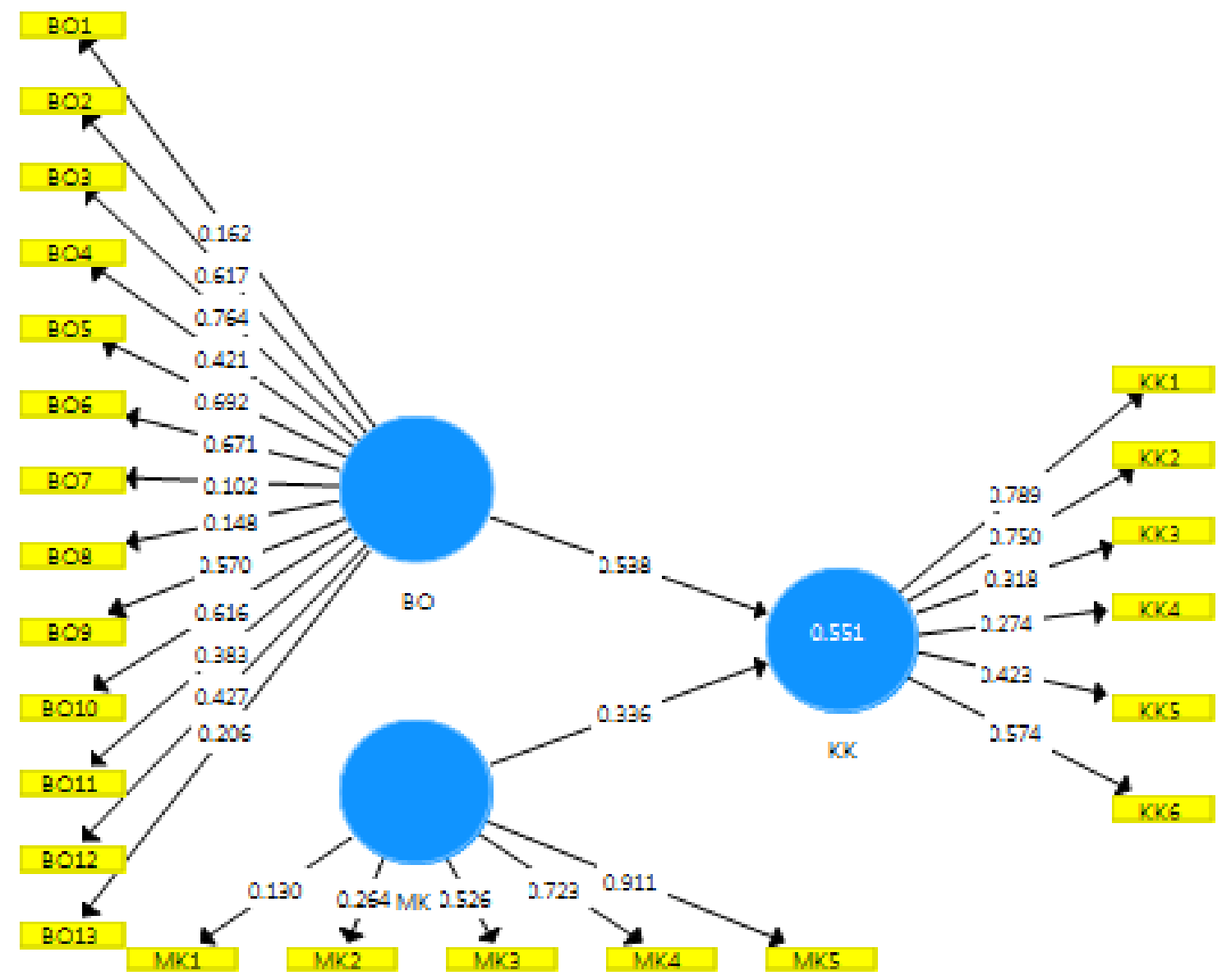

Figure 1. Path Diagram Phase 1

Source: Authors 
After all invalid indicators are excluded from the model, further re-estimation is made using the selected indicators as shown in Figure 2 below.

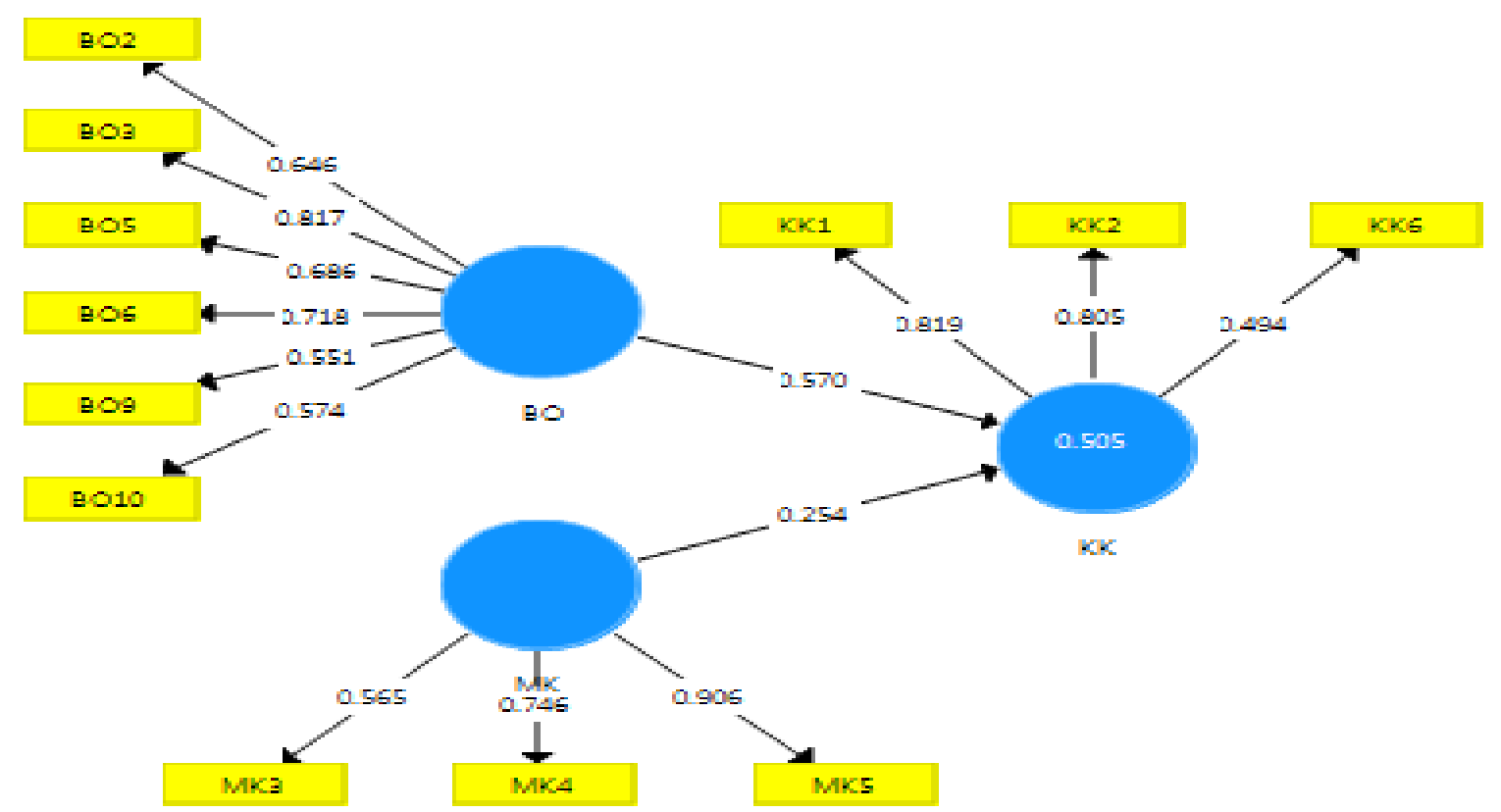

Figure 2. Path Diagram Phase 2

Source: Authors

From picture 2 above, there are still indicators that have less than 0.50 loading factor that is KK6 indicator as representation of latent variable Employee Performance (KK). This indicator is statistically invalid to represent the latent variable Employee Performance, so it must be removed from the model to get a valid model.

By issuing the KK6 indicator of the model, we get a model with indicators that can represent each of its latent variables, as shown in Figure 3 below.

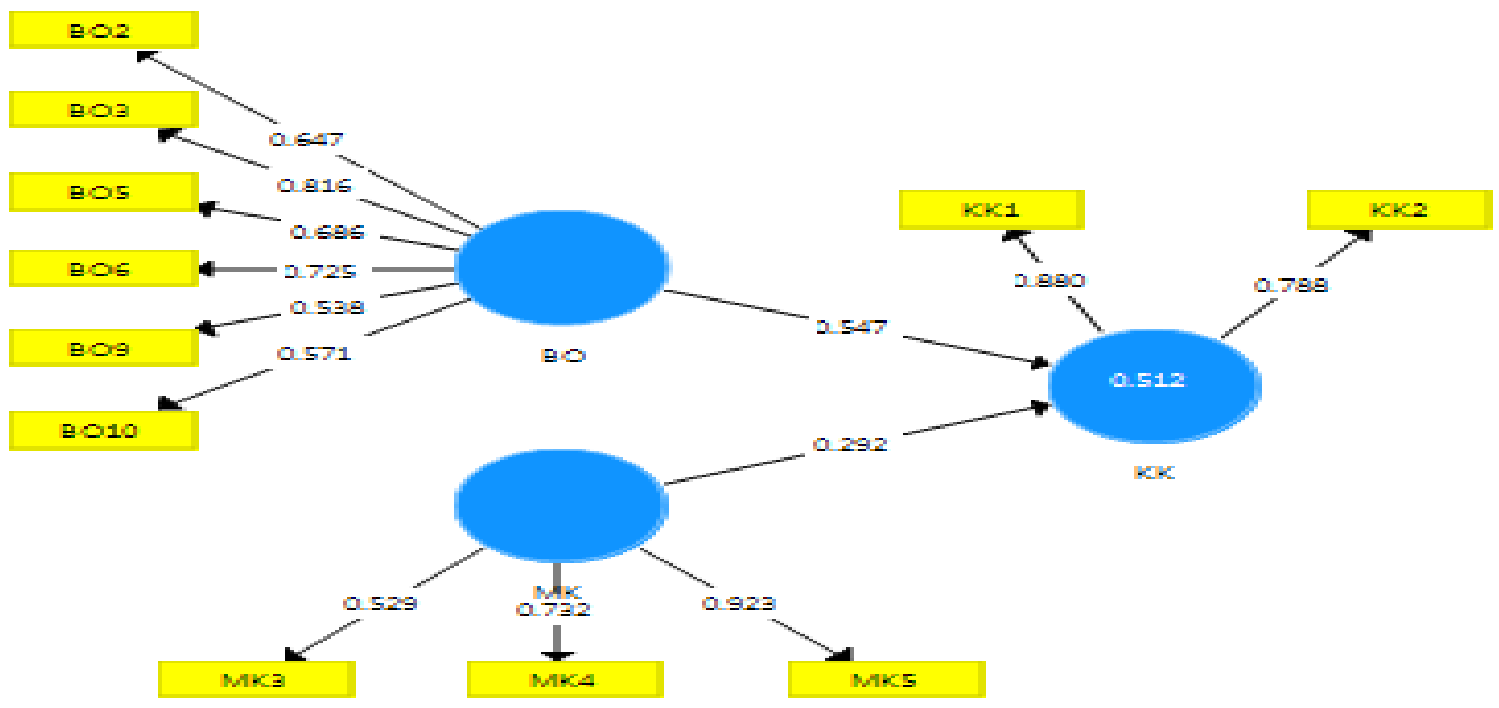

Figure 3. Path Diagram Phase 3

Source: Authors 
To strengthen convergent validity, further testing of the discriminant validity of each selected indicator is necessary to demonstrate that these indicators have only a high correlation with their latent variables but have a low correlation with other latent variables.

The discriminant validity test for each indicator uses the cross-loading value for each indicator compared to the cross-loading indicator value with other latent variables. An indicator can be said to have good and high ability in representing its own latent variables if the value of cross-loading indicator is higher than its cross-loading value with other latent variables. Discriminant validity test results for each indicator are shown in table 5 below.

Table 5. Discriminant Validity Test Results with Cross Loading

\begin{tabular}{cccc}
\hline Indicators & $\begin{array}{c}\text { Organizational Culture } \\
(\mathrm{BO})\end{array}$ & $\begin{array}{c}\text { Work Motivation } \\
(\mathrm{MK})\end{array}$ & $\begin{array}{c}\text { Employee Performance } \\
(\mathrm{KK})\end{array}$ \\
\hline BO2 & 0,571 & 0,36 & 0,269 \\
BO3 & 0,647 & 0,33 & 0,515 \\
BO5 & 0,816 & 0,466 & 0,538 \\
BO6 & 0,686 & 0,169 & 0,601 \\
BO9 & 0,725 & 0,143 & 0,193 \\
BO10 & 0,538 & 0,081 & 0,282 \\
MK3 & 0,172 & 0,880 & 0,147 \\
MK4 & 0,196 & 0,788 & 0,222 \\
MK5 & 0,420 & 0,529 & 0,564 \\
KK1 & 0,538 & 0,630 & 0,732 \\
KK2 & 0,583 & 0,169 & 0,923 \\
\hline
\end{tabular}

Source: Authors

Based on the results in table 5 above, it can be explained that the indicators $\mathrm{BO} 2$, $\mathrm{BO} 3, \mathrm{BO} 5, \mathrm{BO} 6, \mathrm{BO} 9$ and $\mathrm{BO} 10$ are selected as valid indicators for latent variables Organizational Culture (BO) based on convergent validity testing, with its own latent variables rather than its cross-loading value with other latent variables (Work Motivation and Employee Performance). This proves that these indicators are valid indicators to represent latent variables of Organizational Culture.

Similarly, MK3, MK4 and MK5 indicators selected as valid indicators for latent variables of Work Motivation (MK), have greater cross-loading values with latent variables of Work Motivation compared with cross-loading values of latent variables Performance Employees and Organizational Culture.

The KK1 and KK2 indicators as valid indicators to explain the latent variable Employee Performance (KK), also have higher cross-loading on latent variable Employee Performance compared to their cross-loading value against the other two latent variables (Organizational Culture and Work Motivation).

Convert Path Diagram to Equation System. Having obtained valid indicators both convergent and discriminant for each latent variable, then the conversion of the path diagram has been obtained based on figure 3 into the equation system in order to explain the relationship and the influence of each indicator on each of its latent variables (Outer Equation Model). 


\section{Outer Model equations for Latent Variable Organizational Cultur}

$\mathrm{BO}_{2}=0.647 \mathrm{BO} ; \mathrm{BO}_{3}=0.816 \mathrm{BO} ; \mathrm{BO}_{5}=0.686 \mathrm{BO} ; \mathrm{BO}_{6}=0.725 \mathrm{BO} ; \mathrm{BO}_{9}=0.538 \mathrm{BO} ; \mathrm{BO}_{10}=0.571 \mathrm{BO}$

This equation illustrates that the $\mathrm{BO} 3$ indicator is an indicator that gives the highest contribution in representing the latent variable of Organizational Culture compared to 5 other indicators. This means the organizational culture of PT. Inoac Polytechno Indonesia is reflected by employees who are oriented towards high work.

Latent Variables Organizational Culture in PT Inoac Polytechno Indonesia is the smallest reflected by the indicator where every employee is very open with the results of work done, whether the results are good or bad. This empirical evidence is expressed by the contribution of the BO9 indicator which has the lowest contribution compared to other indicators. These findings prove that to build Organizational Culture in PT Inoac Polytechno Indonesia, the company should be more oriented towards how to encourage employees to work with maximum results without forgetting the need for openness from the company to provide input on the work.

\section{Outer Model Equations for Latent Variable Work Motivation}

$$
M K_{3}=0.529 M K ; M K_{4}=0.732 M K ; M K_{5}=0.923 M K
$$

The latent variable of Work Motivation in PT Inoac Polytechno Indonesia are mostly reflected by the MK5 indicator, which means employees will be motivated if given promotion or career development by the company to employees who have achievement, so as to encourage employees to work better. But on the other hand low work motivation is reflected by the recognition of the company to employee productivity in work with a contribution of only 0.529 .

The results of these findings explain that the motivation of employees of PT Inoac Polytechno Indonesia should be built from the promotion of positions and career development of employees who have achievements not just the recognition of the work of these employees.

\section{Outer Model Equations for latent variables Employee Performance}

$$
K K_{1}=0.890 K K ; K K_{2}=0.788 K K
$$

Performance of employees in PT Inoac Polytechno Indonesia based on the results of this study, more reflected from the KK1 indicator, where employees work based on the standards set by the company to achieve quality results and also reflected by employees who can work in accordance with the targets set by company.

Therefore, to improve employee performance, the company should involve employees in determining the standards and targets to be achieved by the company so that the quality of the resulting product can have good quality in accordance with the capabilities possessed by employees.

Testing of Construct Reliability. Construct reliability test is a test done on each construct to determine whether the construct is reliable or not. The criterion of a construct is said to be reliable if the Composite Reliability value of the construct is greater than 0.70 (Garson, 2016; Noor, 2014; Yamin \& Kurniawan, 2011). The result of the Construct Reliability test for each construct as shown in table 6 below. 
Table 6. Testing Results on the Construct Reliability of each variable

\begin{tabular}{lc}
\hline \multicolumn{1}{c}{ Variables } & Composite Reliability \\
\hline Organizational Culture & 0.828 \\
Work Motivation & 0.781 \\
Employee Performance & 0.821 \\
\hline
\end{tabular}

Source: Authors

Based on table 6 above, it can be seen that the value of Composite Reliability of Organizational Culture (BO), Work Motivation (MK) and Employee Performance (KK) is greater than 0.70 so it can be said that all constructs in this study qualify a construct (variable latent) can be said reliabel. This result implies that all latent variables used in the study can be free of errors or without bias and consistently over time using the same indicators (Garson, 2016; Latan, 2014).

Hypothesis Testing. Hypothesis test is a test conducted to determine the strength of the relationship or influence between constructs, namely between exogenous latent variables with endogenous latent variables. The test is done by looking at the coefficient of path (Path Coefficient) and see the value of t-test, if obtained p-value smaller equal to 0.05 it can be said that the influence or relationship between constructs is statistically significant, meaning $\mathrm{H} 1$ acceptable and $\mathrm{H} 0$ rejected. Whereas if the obtained p-value greater than 0.05 then it can be said that the influence or relationship between the constructs are statistically insignificant, meaning $\mathrm{H} 0$ is acceptable and H1 is rejected. (Garson, 2016; Latan, 2014; Noor, 2014; Yamin \& Kurniawan, 2011). Path Coefficient test results are shown in table 7 below.

Table 7. Path Coefficient Test Results

\begin{tabular}{cccccc}
\hline Constructs & $\begin{array}{c}\text { Original Sample } \\
(\mathrm{O})\end{array}$ & $\begin{array}{c}\text { Sample } \\
\text { Mean (M) }\end{array}$ & $\begin{array}{c}\text { Standar Deviation } \\
(\text { STDEV })\end{array}$ & $\begin{array}{c}\text { T-Statistics } \\
(\mid \mathrm{O} / \text { STDEV })\end{array}$ & P-Values \\
\hline $\mathrm{BO}>>$ KK & 0.547 & 0.564 & 0.134 & 4.081 & 0.000 \\
$\mathrm{MK}>>\mathrm{KK}$ & 0.292 & 0.313 & 0.173 & 1.686 & 0.092 \\
\hline
\end{tabular}

Source: Authors

Based on table 7 above, statistically significant influence occurs between latent variable Organizational Culture (BO) to latent variable Employee Performance (KK). This can answer the allegations expressed in hypothesis 1 , where it is suspected that there is a positive influence between the Organizational Culture on Employee Performance. This fact is evidenced by the coefficient value of Organizational Culture variable has positive sign (+) with p-values less than 0.05 .

While the influence of Work Motivation variables on Employee Performance is statistically significant at 90 percent confidence level with a positive direction (+). This fact is in accordance with hypothesis 2 , where there is allegedly a positive influence between Work Motivation and Employee Performance.

Inner Model Equation. The inner model equation is used to find out the effect of exogenous latent variable on the endogenous latent variable. Based on Table 7 on the results of path coefficient testing with smartPLS 3.2.6 program, it can be explained that 
the coefficient of Organization Culture (BO) of 0.547 and the coefficient of Work Motivation (MK) of 0.292 . So the equation model is obtained as follows:

$$
\mathrm{KK}=0.547 \mathrm{BO}+0.292 \mathrm{MK}
$$

The equation has a meaning, Employee Performance 54.70 percent can be explained by the latent variable Organizational Culture (BO), and 29.20 percent described latent variables Work Motivation (MK). This result gives implication to company policy in an effort to improve the performance of the most important employees can be done through the formation and development of organizational culture in the company environment and besides the need for companies to provide motivation to employees both materil and non materil so that employees more productive and spirit in running jobs given to him.

Inner Model Evaluation. Evaluation of inner model is done by three ways, that is by seeing the value of F-Square, R-Square and fit model.

F-Square Test. F-Square test is a test conducted to determine the power of exogenous latent variables to endogenous latent variables at the structural level. If the value is 0.02 , the ability of the exogenous latent variable in explaining the endogenous latent variable is weak, if the value is 0.15 is said to be of moderate capacity and if the value is 0.35 , the exogenous latent variable in explaining endogenous latent variables has strong capabilities (Garson, 2016; Yamin \& Kurniawan, 2011). Here are the results of the F-Square test,

Table 8. F Square Test Results

\begin{tabular}{lcc}
\hline & Constructs & F-Square \\
\hline BO $>$ KK & 0,514 \\
MK $>$ KK & 0,150 \\
\hline
\end{tabular}

Source: Authors

Based on table F-Square above, it can be seen that the strength of Organization Culture (BO) on Work Performance (KK) is equal to 0.514 ; this value is greater than 0.35 so it can be said that Organizational Culture has a strong ability to explain Employee Performance on a structural level. While the power of Work Motivation (MK) on Work Performance $(\mathrm{KK})$ of 0.150 , this shows the ability of variable latent Work Motivation in explaining Employee Performance at the structural level is moderate.

R-Square Adjusted Test. R-Square Adjusted Test is a test conducted to determine the amount of variation of endogenous variables that can be explained by variations of exogenous variables (Garson, 2016; Yamin \& Kurniawan, 2011). R-Square Adjusted value can be seen in table 9 below:

Table 9. R-Square Adjusted Test Result

\begin{tabular}{lc}
\hline & R-Square Adjusted \\
\hline KK & 0.476 \\
\hline
\end{tabular}

Source: Authors

From table 9 above, it can be seen that the magnitude of R Square Adjusted is 0.476 . This means 47.60 percent variation of endogenous variable Employee Performance (KK) which can be explained by exogenous variables Organization Culture (BO) and Work Motivation 
(MK), while the rest of 52.40 percent explained by the variation of changes of variables that are not are included in this model.

Test Fit Model. The fit model test is performed by looking at the NFI values in the model. Normed Fit Index (NFI) is a measure of the conformity of the model with a comparative basis against Base Line or zero. The NFI value will vary from 0 (no fit at all) to 1.0. Based on the statistical table presented by (Bentler, 1990), the good value of NFI conformance for research samples of approximately 50 is above 0.921 ; so it can be said that the model is in accordance with the comparative basis and in accordance with the Base Line. Here is the result of the fit model test.

Table 10. Fit Model Test Results with NFI

\begin{tabular}{ccc}
\hline & Saturated Model & Estimated Model \\
\hline NFI & 0.430 & 0.430 \\
\hline
\end{tabular}

Source: Authors

Based on the above table, it can be seen that the value of Normed Fit Index (NFI) is below 0.921; so it can be said that the model is less fit, which means that the model is said not yet able to reflect the real data. So this model has relatively low ability to explain data and facts.

The Influence of Organizational Culture on Employee Performance. Based on table 7, the result of path coefficient test can be seen that the value of original sample from Organizational Culture to Employee Performance is 0.547 or 54.70 percent, and the pvalues is below 5 percent, so it can be said that Organizational Culture has positive and statistically significant to Employee Performance. Where the organizational culture applied to PT. Inoac Polytechno Indonesia can be a good guide for employees in relation to performance. That is, if PT. Inoac Polytechno Indonesia can continue to improve the existing culture in the company, then the employee performance will be better and high productivity.

The results of this study support the theory put forward by (Umam, 2015) which states that the organizational culture is one asset or organizational resources that make dynamic organizations with physical characteristics (Observable) or nonphysical (Unobservable) is typical as a mechanism in adapting to various changes that take place, contains assumptions, values, norms, commitments and beliefs, and are useful for encouraging and improving the efficiency and effectiveness of public or private organizations.

This is also relevant to the research that has been done by (Shahzad, Iqbal, \& Gulzar, 2013) under the title "Impact of Organizational Culture on Employees Job Performance: An Empirical Study of Software Houses in Pakistan". Where the influence of organizational culture on employee performance is equal to 0.415 or 41.50 percent.

The results of this study indicate that the contribution of organizational culture to employee performance is better, that is equal to 54.70 percent compared with research conducted by (Shahzad et al., 2013).

In addition, this is also relevant to the research already undertaken by (Afnita et al., 2014; Khalig \& Marnis, 2015; Pranoto, 2014; Rimpulaeng \& Sepang, 2014; Setiadi \& Sitohang, 2013; Sulistyaningsih et al., 2012 , Uddin, Luva, \& Hossian, 2013; Wahyuni, 
2015; Zunaidah \& Budiman, 2014) which states that organizational culture has a significant effect on employee performance.

The Influence of Work Motivation on Employee Performance. From table 7 above can be seen that the value of original sample from Work Motivation to Employee Performance is equal to 0.292 or 29.20 percent, and the p-values is above 5 percent, it can be said that Work Motivation positive but statistically insignificant in determine Employee Performance. That is, the higher the company provides work motivation to employees, then it can not make employee performance is increasing. The results of this study are not in line with the theory put forward by (Sutrisno et al., 2016; Suwati, 2013) which states that motivation is a drive caused by an initiative that moves and directs the behavior of individuals to achieve certain goals or incentives.

This is relevant to the research that has been done by (Maramis, 2013) with the title of research "Kepemimpinan, Budaya Organisasi dan Motivasi Pengaruhnya Terhadap Kinerja Karyawan pada PT. Bank Tabungan Negara (Persero) Cabang Manado" where the influence of motivation on employee performance is of 0.050 or 5 percent. From the results of this study it can be seen that the results of this study has a contribution to a better work motivation, which is equal to 29.20 percent compared with research conducted by (Maramis, 2013).

In addition, this is also relevant to the research that has been done by (Dhermawan et al., 2012; Fydayeen et al., 2016; Murti, 2013; Suwati, 2013) which states that the motivation of work has a not significant effect on employee performance.

\section{CONCLUSION AND SUGGESTION}

Conclusion. From the results of the study, it can be concluded that the organizational culture has a positive and statistically significant effect on the performance of employees of PT. Inoac Polytechno Indonesia, Pasar Kemis, Tangerang, while work motivation statistically has no significant effect on employee performance.

Suggestion. Based on the results of research and conclusions obtained, the suggestions that can be submitted are: First, organizational culture have a positive and significant impact on employee performance PT. Inoac Polytechno Indonesia, Pasar Kemis, Tangerang. Based on this, it is important for the company to continue to improve and enhance the organizational culture prevailing within the company. Improving organizational culture can be done by organizing better organizational culture by improving employee work result, employee's accuracy in completing work, good cooperation culture, maintaining culture on time, being open and responsive in facing problems.

Second, employee motivation statistically has no significant effect on employee performance but has positive direction toward employee performance. Therefore, the company still needs to grow employee motivation, because with the motivation, the employees will always feel encouraged and have a high spirit to work better. Growing employee motivation can be done by improving the system promotion and career development for employees who excel, providing effective and efficient facilities to assist employees in completing the work and given attention and small greetings to the employees. 
Third, the Company should continue to maintain and improve employee performance both in terms of quality and quantity. Maintaining and improving the performance of employees in addition to optimizing organizational culture and work motivation as described earlier, can also be done company by increasing other variables not mentioned in this study such as discipline work and good communication between the leadership with employees.

\section{REFERENCES}

Afnita, M., Muis, M., \& Umar, F. (2014). "Pengaruh Budaya Organisasi dan Kompensasi terhadap Kinerja Karyawan di BPJS Ketenagakerjaan Kantor Pusat”. Jurnal Analisis, $3(2), 172-179$.

Aggriawan, K. H., Hamid, D., \& Mukzam, M. D. (2015). "Pengaruh Insentif dan Motivasi terhadap Kinerja Karyawan: Studi Kasus pada Karyawan CV Suka Alam (Kaliwatu Rafting) Kota Batu, Jawa Timur". Jurnal Administrasi Bisnis, 28(1), 50-55.

Bachtiar, D. (2012). "Pengaruh Motivasi dan Lingkungan Kerja terhadap Kinerja Karyawan". Jurnal Analisis Manajemen, 1(1), 1-6.

Bentler, P. . (1990). "Comparative Fit Indexes in Structural Models". Psychological Bulletin, 107(2), 238-246.

Darmawan, D. (2013). Prinsip-prinsip Perilaku Organisasi (1st ed.). Surabaya: Pena Semesta.

Dhermawan, A. A. N. B., Sudibya, I. G. A., \& Utama, I. W. M. (2012). "Pengaruh Motivasi, Lingkungan Kerja, Kompetenti dan Kompensasi terhadap Kepuasan Kerja dan Kinerja Pegawai: Studi Kasus di Lingkungan Kantor Dinas Pekerjaan Umum Provinsi Bali”. Jurnal Manajemen, Strategi Bisnis Dan Kewirausahaan, 6(2), 173184.

Fahrurazi, R., Ghalib, S., \& Arifin, H. (2014). "Pengaruh Komunikasi dan Budaya Organisasi terhadap Kinerja Karyawan PT Bank Pembangunan Daerah Kalimantan Selatan Wilayah Banjarmasin". Jurnal Bisnis Dan Pembangunan, 1(1), 37-46.

Fydayeen, A., Masjaya, \& Prakoso, C. T. (2016). "Pengaruh Kepemimpinan dan Motivasi Kerja terhadap Kinerja Pegawai Bagian Hukum Sekretariat Daerah Kota Samarinda”. eJournal Administrative Reform, 4(3), 735-747.

Garson, G. D. (2016). Partial Least Square: Regression \& Structural Equation Models. North Carolina State Universiryt, USA: Statistical Associates Blue Book Series.

Hendriani, S., \& Hariyandi, F. (2014). "Pengaruh Motivasi dan Komunikasi terhadap Kinerja Pegawai di Lingkungan Sekretariat Daerah Provinsi Riau”. Jurnal Aplikasi Bisnis, 4(2), 124-156.

Kasmir. (2016). Manajemen Sumber Daya Manusia: Teori dan Praktik (1st ed.). Jakarta: Rajawali Press.

Khalig, I., \& Marnis. (2015). "Pengaruh Budaya Organisasi, Disiplin Kerja dan Kepemimpinan terhadap Kinerja Pegawai pada Sekretariat Daerah Kabupaten Indragiri Hulu". Jurnal Tepak Manajemen Bisnis, 7(1), 1-17.

Latan, H. (2014). Aplikasi Analisis Data Statistik untuk Ilmu Sosial Sains dengan STATA. Bandung: Alfabeta.

Lina, D. (2014). "Analisis Pengaruh Kepemimpinan dan Budaya Organisasi terhadap Kinerja Pegawai dengan Sistem Reward sebagai Variabel Moderating”. Jurnal Riset Akuntansi Dan Bisnis, 14(1), 77-97. 
Maabuat, E. S. (2016). "Pengaruh Kepemimpinan, Orientasi Kerja dan Budaya Organisasi terhadap Kinerja Pegawai: Studi Kasus pada Dispenda Sulut UPTD Tondado". Jurnal Berkala Ilmiah Efisiensi, 16(1), 219-231.

Maramis, E. (2013). "Kepemimpinan, Budaya Organisasi dan Motivasi Pengaruhnya terhadap Kinerja Karyawan pada PT Bank Tabungan Negara (PERSERO) Cabang Manado". Jurnal EMBA, 1(4), 955-963.

Masambe, F., Soegoto, A. S., \& Sumarauw, J. (2015). "Pengaruh Gaya Kepemimpinan, Budaya Organisasi dan Inovasi Pemimpin terhadap Kinerja Karyawan Daihatsu Karisma Manado". Jurnal EMBA, 3(3), 939-949.

Murti, H. (2013). "Pengaruh Motivasi terhadap Kinerja Pegawai dengan Variabel Pemediasi Kepuasan Kerja pada PDAM Kota Madiun”. Jurnal Riset Manajemen Dan Akuntansi, 1(1), 10-17.

Noor, J. (2014). Analisis Data Penelitian Ekonomi \& Manajemen (1st ed.). Jakarta: PT.Gramedia Widiasarana Indonesia.

Pranoto, P. S. (2014). "Pengaruh Budaya Organisasi dan Motivasi Kerja terhadap Kinerja Karyawan”. Jurnal Ilmu Manajemen, 2(4), 1492-1502.

Putri, R. E. (2015). "Hubungan Budaya Organisasi dengan Kinerja Pegawai pada Kantor Badan Pengendalian Dampak Lingkungan Daerah Kota Padang". Jurnal Administrasi Pendidikan, 1(11), 1-29.

Rimpulaeng, K., \& Sepang, J. L. (2014). "Motivasi Kerja, Komitmen Karyawan dan Budaya Organisasi Pengaruhnya terhadap Kinerja Karyawan PT Gudang Garam Manado". Jurnal EMBA, 2(3), 137-148.

Sari, R., Muis, M., \& Hamid, N. (2012). "Pengaruh Kepemimpinan, Motivasi dan Stress Kerja terhadap Kinerja Karyawan pada Bank Syariah Mandiri Kantor Cabang Makassar". Jurnal Analisis, 1(1), 87-93.

Satyawati, N. M. R., \& Suartana, I. W. (2014). "Pengaruh Gaya Kepemimpinan dan Motivasi terhadap Kepuasan Kerja yang Berdampak pada Kinerja Keuangan”. Jurnal Akuntansi Universitas Udayana, 6(1), 17-32.

Setiadi, A., \& Sitohang, S. (2013). "Pengaruh Motivasi, Lingkungan Kerja dan Komunikasi Inten terhadap Kinerja Karyawan UD Rezeki Surabaya”. Jurnal Ilmu Dan Riset Manajemen, 2(11).

Shahzad, F., Iqbal, Z., \& Gulzar, M. (2013). "Impact of Organizational Culture on Employees Job Performance: An Empirical Study of Software Houses in Pakistan". International Journal of Business Studies Quarterly, 5(4), 56-64.

Sugiyono. (2016). Metode Penelitian Kuantitatif, Kualitatif dan $R \& D$ (23rd ed.). Bandung: Alfabeta.

Sulistyaningsih, Dewi, A. S., \& Wijayanti, Y. T. (2012). "Pengaruh Budaya Organisasi terhadap Kinerja Karyawan: Studi Kasus UIN Sunan Kalijaga Yogyakarta". Jurnal Sosiologi Reflektif, 6(2), 89-101.

Sutrisno, Fathoni, A., \& Minarsih, M. M. (2016). "Pengaruh Motivasi dan Disiplin Kerja terhadap Kinerja Pegawai di Kantor Satuan Polisi Paming Praja Kota Semarang”. Journal of Management, 2(2), 1-12.

Suwati, Y. (2013). "Pengaruh Kompensasi dan Motivasi Kerja terhadap Kinerja pada PT Tunas Hijau Samarinda". Jurnal Ilmu Administrasi Bisnis, 1(1), 41-55.

Tampi, B. J. (2014). "Pengaruh Gaya Kepemimpinan dan Motivasi terhadap Kinerja Karyawan pada PT Bank Negara Indonesia Tbk (Regional Sales Manado)”. Jurnal Acta Diurna, 3(4), 1-20. 
Trang, D. S. (2013). "Gaya Kepemimpinan dan Budaya Organisasi Pengaruhnya terhadap Kinerja Karyawan: Studi Kasus pada Perwakilan BPKP Provinsi Sulawesi Utara". Jurnal EMBA, 1(3), 208-216.

Uddin, M. J., Luva, R. H., \& Hossian, S. M. M. (2013). "Impact Organizational Culture on Employee Performance and Productivity: A Case Study of Telecommunication Sector in Bangladesh". International Journal of Business and Management, 8(2), 6377.

Umam, K. (2015). Manajemen Organisasi (2nd ed.). Bandung: CV Pustaka Setia.

Wahyuni, E. (2015). "Pengaruh Budaya Organisasi dan Gaya Kepemimpinan terhadap Kinerja Pegawai Bagian Keuangan Organisasi Sektor Publik dengan Motivasi Kerja sebagai Variabel Intervening: Studi Kasus pada Pegawai Pemerintah Kota Tasikmalaya". Jurnal Nominal, 4(1), 96-112.

Yamin, S., \& Kurniawan, H. (2011). Generasi Baru Mengolah Data Penelitian dengan Partial Least Square Path Modeling: Aplikasi dengan Software XLSTAT, SmartPLS dan Visual PLS (1st ed.). Jakarta: Salemba Infotek.

Zainal, V. R., Ramly, M., Mutis, T., \& Arafah, W. (2014). Manajemen Sumber Daya Manusia untuk Perusahaan (3 (6)). Jakarta: Rajawali Press.

Zunaidah, \& Budiman, A. N. A. (2014). "Analisis Pengaruh Motivasi dan Budaya Organisasi terhadap Kinerja Karyawan: Studi Kasus Business Unit SPBU PT Putra Kelana Makmur Group Batam”. Jurnal Manajemen Dan Bisnis Sriwijaya, 12(1), 4554. 